Original Article

\title{
ANTIOXIDANT, ANTIMICROBIAL ACTIVITY AND TOTAL PHENOL AND FLAVONOIDS ANALYSIS OF SAMBUCUS NIGRA (ELDERBERRY)
}

\author{
N. SRINIVAS GOUD¹, GOBIND PRASAD ${ }^{2}$ \\ ${ }^{1}$ Renatus Wellness Pvt. Ltd. Hyderabad, 500051, India, ${ }^{2 B i n o d ~ B i h a r i ~ M a h a t o ~ K o y a l a n c h a l ~ U n i v e r s i t y, ~ D h a n b a d, ~ I n d i a ~}$ \\ Email: rohit@renatuswellness.net
}

Received: 15 Sep 2019, Revised and Accepted: 25 Nov 2019

\section{ABSTRACT}

Objective: The goal of this study was paying attention on the chemical characterization of phytochemical compounds and their antioxidant activity of Sambucus nigra L.

Methods: Phytochemical analysis was performed by Sambucus nigra L fruit extract. Total Phenol and Flavonoids content of elderberry fruit extract also determined using Folin-Ciocalteu colorimetric method and aluminum chloride colorimetric method. Antibacterial activity was performed by disk diffusion method and Antioxidant capacity was investigated by DPPH assay, butylhydroxytoluene used as a standard.

Results: The richest anthocyanin in elderberry fruits was cyanidin-3- $O$-sambubioside. The antioxidant capacity obtained for elderberry extract proved that elderberry shown highest antioxidant activity, being the richest anthocyanins. The antioxidant capacity of elderberry fruit methanolic extract was recorded $62.56 \pm 1.12$ percentages of scavenging activity. We also investigated antibacterial activity against four species Escherichia coli, Pseudomonas putida, Bacillus cereus, and Staphylococcus aureus. There E. coli was recorded $12.0 \mathrm{~mm}$ and Pseudomonas putida was recorded 0.34 mm zone of inhibition.

Conclusion: The conclusion of our study is that Sambucus nisgra fruit extract has very high antioxidant activity which makes it recommendable for food industry and dietary supplement.

Keywords: Antioxidant, Phytochemical, Sambucus nigra, Anthocyanin, Antimicrobial activity

(C) 2020 The Authors. Published by Innovare Academic Sciences Pvt Ltd. This is an open access article under the CC BY license (http://creativecommons.org/licenses/by/4.0/]

DOI: http://dx.doi.org/10.22159/ijcpr.2020v12i1.36829. Journal homepage: https://innovareacademics.in/journals/index.php/ijcpr

\section{INTRODUCTION}

Sambucus nigra L. belong to Adoxaceae family, which growing on sunlight-exposed locations in Europe. Sambucus nigra L. currently, more consideration has been focused on natural compounds that may valuable in dropping oxidative stress-induced diseases. Elderberries contain flavonols glycosides, organic acids and anthocyanins [1, 2]. However, the anthocyanins present in elderberries are showing important for favorable health effects related with their antioxidant activity and their capability has been recorde to protect against influenza $A$ and $B$ virus, colon cancer respective Helicobacter pylori infections [3-5]. There are numerous studies behind the idea that elderberry is an accurate pharmacy, measured to be an abundant source of bioactive components, which it is offered in modern medicine.

The elderberry contains numerous compounds that may supply to pharmacological activities. High amounts of anthocyanins like cyanidin-3-sambubioside and cyanidin-3-glucoside. Less amounts of other kinds of flavonols, anthocyanins, phenolic acids and procyanidins have also been investigated [6]. Some other components were also identified such as vitamins, minerals carbohydrates include $7.5 \%$ glucose, pectin and fructose [7].

The consumption of elderberry helps to prevent and therapy for many diseases, like diabetes, obesity, immune system stimulation, antibacterial and antifungal activity, antitumor activity, diuretic and laxative activity, protection against UV radiation [8-14].

Bioactive compounds of plants responsible for their antimicrobial properties include alkaloids that damage the DNA of microbial cells and most important to cell death [15]. The major components are liable for the antimicrobial properties of plants, which is polyphenolic compound. They display anti-inflammatory activity in vitro and in vivo and mechanism of the inhibition of enzymes [16, 17].

The antioxidant activity of elderberry anthocyanins and flavonols is due to the being there of meta 5,7-dihydroxy arrangements in the A ring and ortho 3',4'-dihydroxy moiety in the B ring [18]. Phenolics compounds present in berries is affected only by genetic differences, environmental conditions, degree of maturity is most important for pharmaceutical industry to know the chemical composition and the antioxidant capacity [19].

The purpose of this study was to establish the phytochemical screening, total phenol and Flavonoids content analysis and antimicrobial effects of elderberry fruit. Antioxidant properties of elderberry fruit also investigated.

\section{MATERIALS AND METHODS}

\section{Materials and chemicals}

The elderberry fruits was purchased from traditional local suppliers of medicinal herbs. gallic acid, anhydrous sodium carbonate, 2,2diphenyl-1-picrylhydrazyl hydrate (DPPH., 95\%) were obtained from sigma-aldrich (Steinheim, Germany). Folin-ciocalteu phenol reagent, methanol, acetone were procured from merck.

\section{Extract preparation}

$50 \mathrm{~g}$ of dried fruit powder was soaked in $200 \mathrm{ml}$ of methanol for 48 $h$. The extract was filtered and evaporated at the room temperature. obtained residues were resuspended in methanol.

\section{Bacterial strains}

The bacterial isolates Escherichia coli, Pseudomonas fluorescens, Bacillus cereus, and Staphylococcus aureus were procured from MTCC Chandigarh. The bacteria were maintained on nutrient agar.

\section{Phytochemical screening}

The phytochemical analysis of phenolics, terpenoids, phytosterols, flavonoids, carbohydrates, glycosides, saponins tannins and alkaloids in methanol elderberry extracts were performed using previously described procedures of A. Sofowora [20]. 


\section{Total phenolic content}

The total phenol content was determined by the Folin-Ciocalteu colorimetric method with some modification [21]. Briefly, $0.025 \mathrm{ml}$ of plant extract, $0.125 \mathrm{ml}$ of Folin-Ciocalteu reagent and $1.975 \mathrm{ml}$ of distilled water were mixed carefully. After $3 \mathrm{~min}, 0.375 \mathrm{ml} 20 \%$ sodium carbonate was added. Mixture was incubated in dark condition, at room temperature for $2 \mathrm{~h}$. the observance was recorded at $750 \mathrm{~nm}$. The results were expressed as mg of gallic acid equivalents (GAE)/g DW. gallic acid used as a standard. All tests were done in triplicates.

\section{Total flavonoid content}

The total flavonoid content was determined using the aluminum chloride colorimetric method [22]. Briefly, $0.25 \mathrm{ml}$ of extract was added to $1 \mathrm{ml}$ distilled water. Then $5 \%$ of $0.075 \mathrm{ml}$ of sodium nitrite was added. After $5 \mathrm{~min}, 10 \%$ of $0.075 \mathrm{ml}$ of aluminum chloride was added. After $6 \mathrm{~min}, 0.5 \mathrm{ml}$ of $1 \mathrm{~mol} / \mathrm{l}$ sodium hydroxide solution and the volume was makeup to $2.5 \mathrm{ml}$ with distilled water. The absorbance was recorded at $510 \mathrm{~nm}$. Rutin used as a standard. The results were expressed as mg of rutin equivalents (RE)/g DW.

\section{Antimicrobial activity}

The antibacterial activity of the methanolic extract was investigated by the disk diffusion method, on Mueller Hinton Agar medium. The experiment was performed by using $24 \mathrm{~h}$ old bacterial suspension. The extract was tested using $5 \mathrm{~mm}$ sterilized filter paper discs. The discs were impregnated with $20 \mu \mathrm{l}$ of the extract, kept to dry under laminar airflow and then placed into previously inoculated Petri dishes. Subsequently, the plates were incubated for $24 \mathrm{~h}$ at $37^{\circ} \mathrm{C}$. Standard antibiotic discs used as positive controls for the antimicrobial activity. After incubation, the diameter zone of inhibition was measured.

\section{DPPH radical scavenging activity}

The DPPH assay was performed previously describe method by Brand-Williams [23]. Briefly, $1 \mathrm{ml}$ of DPPH solution was allowed to react with $1 \mathrm{ml}$ extract. The capacity of the polyphenolic compounds, which is act as free radical scavengers against DPPH radical. After 30 min at $40{ }^{\circ} \mathrm{C}$ the absorbance was recorded at $517 \mathrm{~nm}$, against a blank. Standard curve was organized using diverse concentrations of butylhydroxytoluene and the results were presented as the percent of control.

The antioxidant activity was calculated as follows:

$\%$ DPPH scavenging activity $=\left(1-\left[\right.\right.$ Asample $/$ Acontrol $\left.\left.\mathrm{t}=0_{0}\right]\right) 100$

\section{RESULTS}

\section{Phytochemical screening}

The phytochemical screening result of elderberry methanol extract revealed the presence of phenols, flavonoids, tannins, anthocyanin and carbohydrates. There alkaloids and saponins were not detected (table 1).

\section{Total phenols and flavonoids content}

The most important groups of compounds being responsible for antimicrobial activity include Phenolics and Flavonoids. The variation in the antimicrobial effect that may become from the variations in the structure and chemical composition of these compounds.

The total phenolic content elderberry was determined using folinciocalteau method. TPC was recorded $43 \pm 0.98 \mathrm{mg} \mathrm{GAE} / \mathrm{g}$ DW. The total Flavonoid content was recorded $15 \pm 1.12$ mg rutin equivalents/g DW (table 2).

\section{Antibacterial activity}

Antimicrobial activity of elderberry fruit extract were presented in table 3. Antibiotic effect depended on the solvent used for extraction. After eliminating, most important zone of inhibition found against $(12.0 \mathrm{~mm})$ E. coli. Elderberry methanol extract also shown less zone of inhibition $(0.33 \mathrm{~mm})$ against Pseudomonas pudita. However, Bacillus cereus and Staphylococcus aureus were not recorded inhibition zone. Antibacterial activity results were presented in table 3.

\section{Antioxidant activity DPPH assay}

The antioxidant activity of elderberry fruit extract was determined by DPPH assay. Antioxidant activity result was presented in table 4 The method used is for the reduction of the radical DPPH in the presence of hydrogen donating antioxidants.

Table 1: Phytochemmical screening of elderberry fruit

\begin{tabular}{ll}
\hline Phytochemical compounds & Methanol extract \\
\hline Alkaloids & $-\mathrm{ve}$ \\
Phenols & $+\mathrm{ve}$ \\
Flavonoids & $+\mathrm{ve}$ \\
Tannins & $+\mathrm{ve}$ \\
Saponins & $-\mathrm{ve}$ \\
Anthocyanin & $+\mathrm{ve}$ \\
Sterols & $+\mathrm{ve}$ \\
Carbohydrates & $+\mathrm{ve}$ \\
\hline
\end{tabular}

Table 2: Total phenol and flavonoids content analysis of elderberry fruit extract

\begin{tabular}{lll}
\hline Extract & Total phenols content & Total flavonoids content \\
\hline Methanol extract & $43 \pm 0.98 \mathrm{mg} \mathrm{GAE} / \mathrm{g} \mathrm{DW}$ & $15 \pm 1.12 \mathrm{mg}$ rutin/g DW \\
\hline
\end{tabular}

Table 3: Antibacterial activity of methanol extract of elderberry fruit

\begin{tabular}{ll}
\hline Bacterial name & Zone of inhibition (mm) \\
\hline Escherichia coli & 12.0 \\
Pseudomonas pudita & 0.34 \\
Bacillus cereus & - \\
Staphylococcus aureus & - \\
\hline
\end{tabular}

Table 4: Antioxidant activity of elderberry fruit methanol extract

\begin{tabular}{ll}
\hline Extract & DPPH radical scavenging activity (\%) \\
\hline Methanol extract & $62.56 \pm 1.12$ \\
\hline
\end{tabular}




\section{CONCLUSION}

Elderberries are predominately used as food and dietary supplements, for that reason it is very important useful to know their compounds such as phenolic and flavonoids. Sambucus nigra contained mainly anthocyanins as cyanidin 3-O-sambubioside and cyanidin 3-glucoside. In this study we conclude phytochemical analysis, Total Phenol and Flavonoids and antibacterial activity against four species.

\section{FUNDING}

Nil

\section{AUTHORS CONTRIBUTIONS}

All the authors have contributed equally.

\section{CONFLICTS OF INTERESTS}

Declared none

\section{REFERENCES}

1. JI Nakajima, I Tanaka, S Seo, M Yamazaki, K Saito. LC/PDA/ESIMS profiling and radical scavenging activity of anthocynins in various berries. J Biomed Biotechnol 2004; 5:241.

2. $\mathrm{X} \mathrm{Wu}, \mathrm{L}$ Gu, RL Prior, S Mckay. Characterization of anthocyanins and proanthocyanidins in some cultivars of ribes, aronia, and sambucus and their antioxidant capacity. J Agric Food Chem 2004;52:7846.

3. P Jing, JA Bomser, SJ Schwartz, J He, BA Magnuson, MM Giusti. Structure-function relationships of anthocyanins from various anthocyanin-rich extracts on the inhibition of colon cancer cell growth. J Agric Food Chem 2008;56:9391.

4. S Zafra Stone, T Yasmin, M Bagchi, A Chatterjee, JA Vinson, D Bagchi. Berries anthocynins as nowel antioxidant in human health and diseases prevention. Mol Nutr Food Res 2007;51:675-83.

5. Z Zakay Rones, E Thom, T Wollan, J Wadstein. Randomized study of the efficacy and safety of oral elderberry extract in the treatment of influenza a and b virus infections. J Int Med Res 2004;32:132.

6. Fossum G, Malterud KE, Moradi A, S Nigra, L Flos. Assessment report for the development of community monographs and for inclusion of herbal subtsance(s), preparation(s) or combinations ther of in the list. European Medicines Agency (EMA): London; 2008.

7. Veberic R, Jakopic J, Stampar F, Schmitzer V. European elderberry (Sambucus nigra L.) rich in sugars, organic acids, anthocyanins and selected polyphenols. Food Chem 2009;114:511-5.
8. Bhattacharya S, Christensen KB, Olsen LCB, Christensen LP, Grevsen K, Færgeman NJ, et al. Bioactive components from flowers of Sambucus nigra L. increase glucose uptake in primary porcine myotube cultures and reduce fat accumulation in caenorhabditis elegans. J Agric Food Chem 2013;61:11033-40.

9. Beaux D, Fleurentin J, Mortier F. Effect of extracts of orthosiphon stamineus benth, hieracium pilosella L., sambucus L. and arctostaphylos uva-ursi (L.) spreng in rats. Phytother Res 1999;13:222-5.

10. Chen L, Hu JY, Wang SQ. The role of antioxidants in photoprotection: a critical review. J Am Acad Dermatol 2012; 67:1013-24.

11. Chrubasik C, Maier T, Dawid C, Torda T, Schieber A, Hofmann T, et al. An observation study and quantification of the actives in a supplement with sambucus nigra and asparagus officinalis used for weight reduction. Photother Res 2008;22:913-8.

12. Folmer F, Basavaraju U, Jaspars M, Hold G, El-Omar E, Dicato M, et al. Anticancer effects of bioactive berry compounds. Phytochem Rev 2014;13:295-322.

13. Gray AM, Abel Wahab YHA, Flatt PR. The traditional plant treatment, Sambucus nigra (elder), exhibits insulin-like and insulin-releasing actions in vitro. J Nutr 2000;113:15-20.

14. Picon PD, Picon RV, Costa AF, Sander GB, Amaral KM, Aboy AL, et al. Randomized clinical trial of a phytotherapic compound containing pimpinella anisum, foeniculum vulgare, sambucus nigra, and cassia augustifolia for chronic constipation. BMC Complementary Altern Med 2010;10:17.

15. Omulokoli E, B Khan, SC Chhabra. Antiplasmodial activity of four kenyan medicinal plants. J Ethnoph 1995;56:133-7.

16. Coban EP, H Biyik. Antimicrobial activity of ethanol extracts of some plants natural growing in Aydin, Turkey. Afr J Microbiol Res 2010;4:2318-23.

17. Kim J, MR Marshall, C Wei. Antibacterial activity of some essential oils components against five foodborne pathogens. J Agric Food Chem 1995;43:2839-45.

18. C Rice Evans, N Miller, G Paganga. Antioxidant properties of phenolic compounds. Trends Plant Sci 1997;2:152.

19. R Zadernowski, M Naczk, J Nesterowicz. Phenolic acid profiles in some small berries. J Agric Food Chem 2005;53:2118.

20. Sofowora. Recent trends in research into African medicinal plants. J Ethnopharmacol 1993;38:209.

21. VL Singleton, JA Rossi. Colorimetry of total phenolics with phosphomolybdic phosphotungstic acid reagents. Am J Enol Viticulture 1965;16:144-58.

22. CC Chang, MH Yang, HM Wen, JC Chern. Estimation of total flavonoid content in propolis by two complementary colorimetric methods. J Food Drug Anal 2002;10:178-82.

23. W Brand Williams, ME Cuvelier, C Berset. Use of a free radical method to evaluate antioxidant activity. LWT Food Sci Technol 1995;28:25. 